\title{
What seems new is sometimes old in haematology and wine
}

\author{
Shaun R. McCann $\mathbb{1}^{1}$
}

Received: 26 March 2021 / Revised: 30 March 2021 / Accepted: 9 April 2021 / Published online: 3 May 2021

(c) The Author(s), under exclusive licence to Springer Nature Limited 2021

\author{
'Old things are always in good repute, present things \\ in disfavour' \\ Gaius Cornelius Tacitus. 65-125 CE \\ Roman Historian.
}

It's a common belief, and sometimes but not always, a fallacy, that things were better in a distant 'golden age'. However, there is no doubt that some eras promote more nostalgia than others. Many young people now (under the age of 45) hanker after the $70 \mathrm{~s}$. There is no doubt it was an exciting time and social attitudes were changing dramatically e.g. anti-Vietnam demonstrations, the growth of feminism and anti-establishment views. I received my haematology training at the University of Minnesota. I had long hair and wore bell-bottomed jeans. If I remember correctly, the only rule in the department was the requirement to wear shoes and a shirt.

If we take a close look at haematology we find, in some instances, that things that were done many years or millennia ago are still useful today. Let's look at leeches. Some of us will remember the chilling scene of Katherine Hepburn removing leeches from Humphrey Bogart in the film 'The African Queen' (Director, John Huston 1951). Leeches, as we know, have been used since ancient Egyptian times until the present day as ways of removing blood or increasing blood flow to delicate tissues. Like vitis vinifera, they are hermaphrodites [1] and are oviparous, their eggs varying from six to fifteen [2]. Deposited near the edge of water the eggs hatch by the heat of the sun. 'They are aquatic worms... and belong to the Phylum Annelida family of fresh-water parasitic invertebrates' [2, 3]. According to Hyson, French soldiers drank water from leech-infested ponds during Napoleon's attempted

Shaun R. McCann

shaunrmccann@gmail.com

1 Emeritus, Department of Haematology, Trinity College, Dublin, Ireland conquest of Egypt. The leech larvae swelled, after gorging on blood, in the respiratory tract, causing death from haemorrhage or suffocation.

As medical treatment, leeches became popular in the 17th, 18th and 19th century, [Fig. 1]. In the early and mid 19th century leeches were favoured by dentists until a patient died shortly after application of a leech for a toothache. However, leeches are apparently still used by plastic surgeons after limb

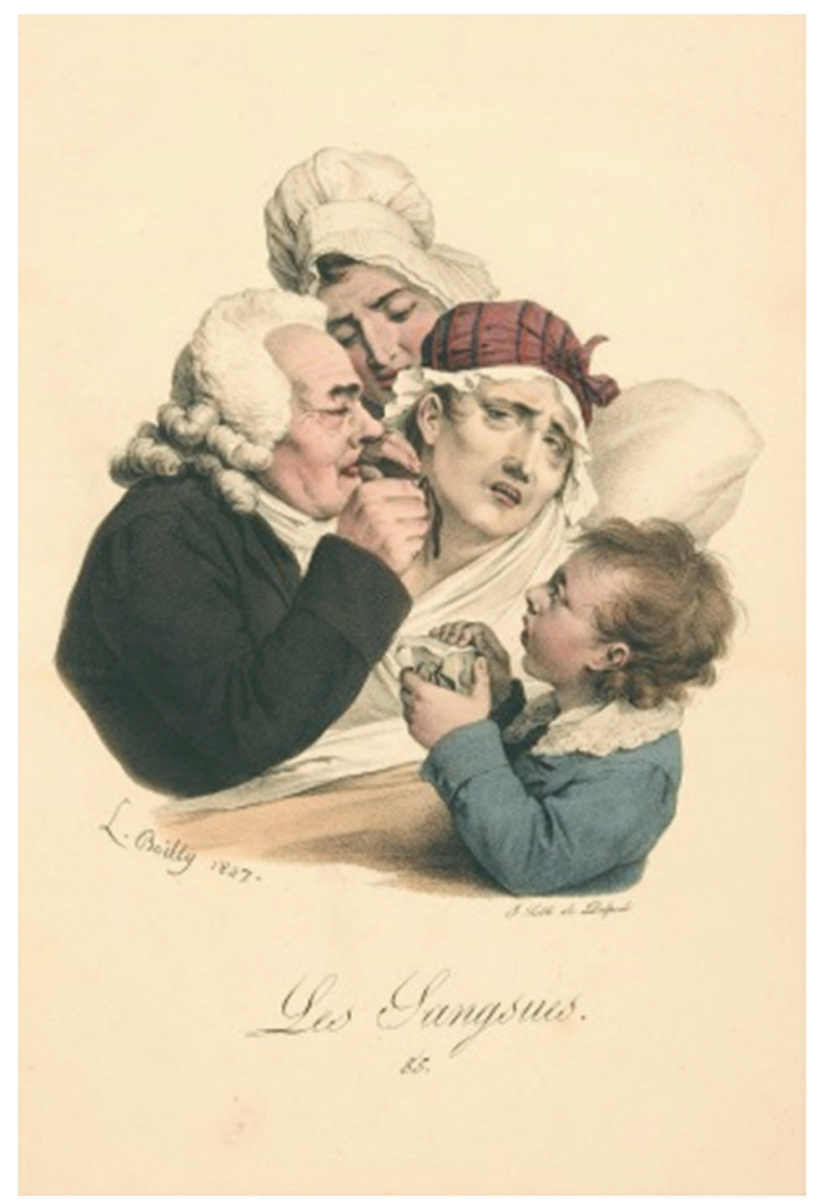

Fig. 1 Leeches. A medical practitioner administers leeches to a patient. Colour lithograph after L. Boilly, 1827. From the Wellcome Collection, free to use with attribution (CCBY 4.0). 
reattachment, for their anti-coagulant properties. In 1884, John Berry Haycroft, discovered the anticoagulant 'hirudin' that the leech injects into blood. Hirudin is an anti-thrombin and is now available as, argatroban, which binds reversibly to thrombin and bivalirudin. Both of these agents have been licenced for the treatment of Heparin Induced Thrombocytopenia Syndrome (HITS) and are more frequently used in the United States than Europe (personal communication from Dr Adam Cuker, University of Pennsylvania).

Bloodletting we know was a form of therapy used 'to re-align the disrupted humours' since the time of Galen. Unfortunately, it was used by physicians long after its benefits had been disproved. It is said that George Washington almost succumbed to overzealous bloodletting [4]. Although bloodletting, as a common therapy, is no longer practised, the removal of blood is indicated in the treatment of hemochromatosis, polycythaemia vera, porphyria cutanea tarda, sickle cell disease, and non-alcoholic fatty liver disease with hyperserotonaemia and for some high affinity haemoglobins [5].

Drug development is a relatively new phenomenon but sometimes politics, among other factors, can influence regulatory approval. Bendamustine, is an alkylating agent developed by Ozegowski and Krebs in 1963 in the German Democratic Republic (East Germany) had a long gestation period and only received FDA approval in 2008 .

In the winemaking business have some old techniques been reborn? Yes. The first one that comes to mind is cement (cement and concrete are often used interchangeably). Although the Romans used cement tanks about 2000 years ago, they have become fashionable again. Square open-top cement/concrete fermentation tanks are being used in Burgundy and also in the southern Rhône valley. They are also used in the fermentation of Château Petrus, (Bordeaux), and in Argentina for centuries. Cement tanks can be egg-shaped [6] and may be unlined or lined with epoxy resin (the Romans certainly didn't have epoxy resin). Cement is porous, so air is able to permeate the wine via countless tiny holes. Some wine makers don't like lined cement tanks as epoxy resin is air-tight. Cleaning cement tanks could also be a problem. Enclosed tanks had a very small opening so children were used to get inside to clean them. Egg-shaped cement tanks are gaining in popularity in California.

Amphorae [Fig. 2], made of clay, have been used for fermentation of wine since ancient Egyptian days. The Greeks and Romans introduced them to Italy, Spain and France. In some instances, they were buried in soil, in some half-buried or not buried at all. Like cement, they are organic and some wine makers claim that there is no need to add sulfur during wine fermentation (sulfur inhibits oxidation and acts as an anti-bacterial and anti-yeast). Although

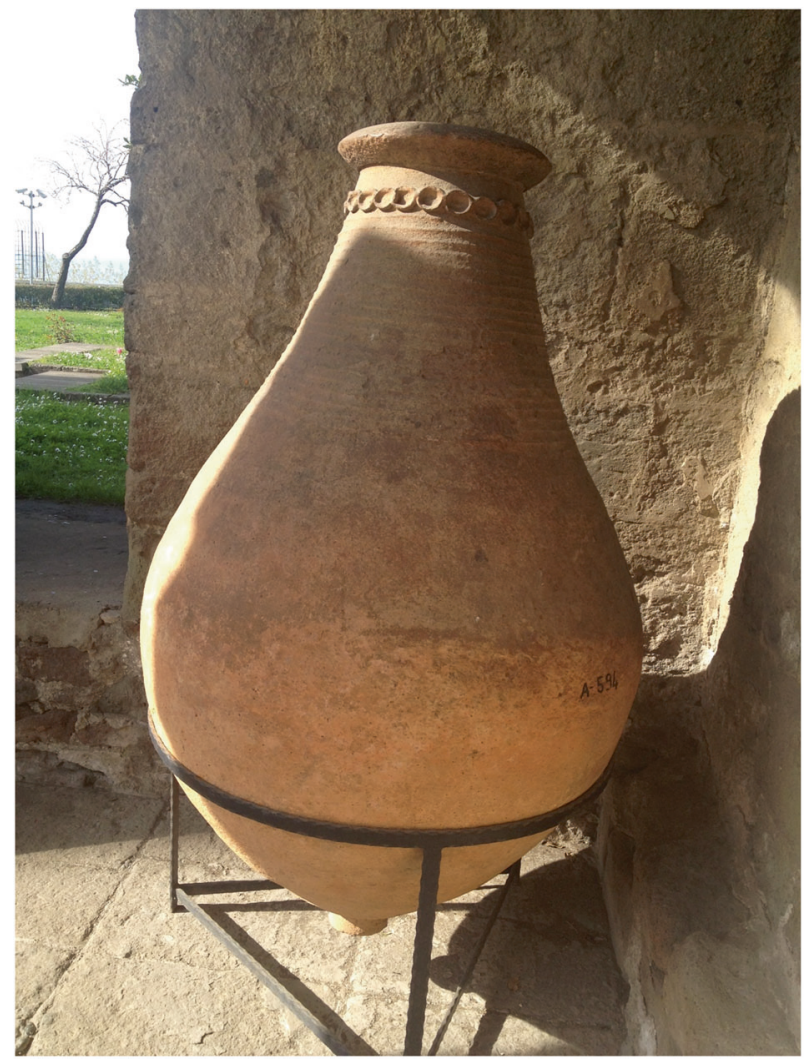

Fig. 2 Amphora. Amphora in Eastern Turkey. Photograph Shaun R. McCann.

they had been used for 3-4000 years, and in Spain for over 100 years they are now making a comeback, being used in Corsica, parts of France, Sicily, Croatia, Portugal, parts of Italy and Georgia (one of the earliest countries to use amphorae). Their current popularity, no doubt, is due to the 'green' movement and the desirability of minimal intervention in the fermentation process.

Although the Romans used glass, wine bottles, have their origin in the 16th/17th centuries [7]. According to Hugh Johnson, Sir Kenelm Digby, in the middle of the 17th century started making glass wine bottles that were 'thicker, heavier, stronger and darker - and cheaper than any known before'. Wine labels, on the other hand, have been around for a long time. They were discovered in the tomb of King Tutankhamun, containing information about the grape variety, vintage, region and year of the wine contents [8]. Something approximating to the labels we know to-day were produced by Dom Pérignon in the 17th century. These were hand written and tied to the bottle neck with string. Many of you will have visited Chianti in Italy and tasted well-made Chianti Classico. But the area of Chianti was designated by the Grand Duke of Tuscany [9], Cosimo de Medici III in 1716 [Fig. 3] to become the world's first legal appellation of origin. Since then, there are many 


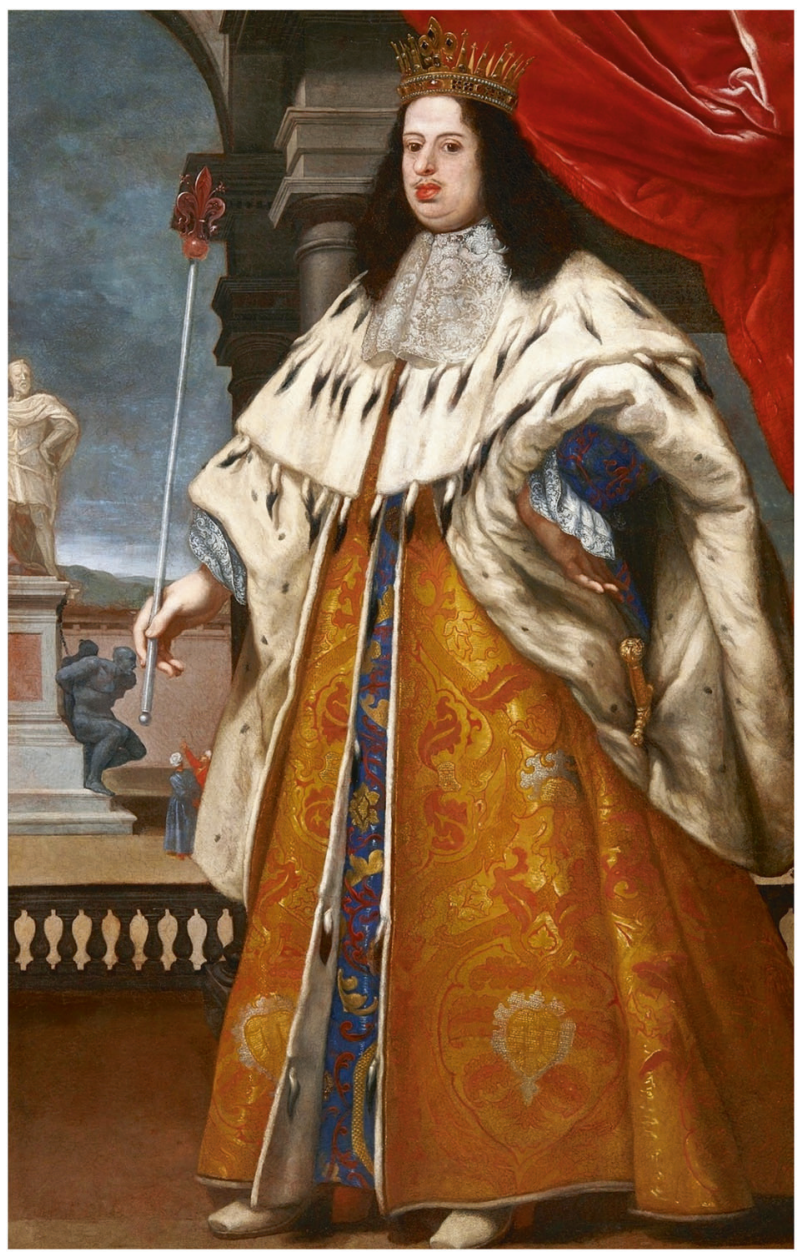

Fig. 3 Cosimo III. Cosimo III, Grand Duke of Tuscany. Royal Castle, Warsaw, Poland. Public domain.

'appellations' which help us to determine the origin of the beverage we are drinking.

Vine training, better known as canopy management, has also been around since ancient times. It is used to protect vines and their fruit from adverse weather conditions and to improve grape yields. Vines are by nature climbing plants and were originally supported by tree trunks. The Egyptians and Phoenicians used reeds and wicker to tie vines to trellises and encouraged rigorous pruning. Although the Romans had a major impact on wine making in Italy, France and Spain, the Carthaginians added significantly to viticultural methodology. The Goblet method, where the vines are kept short and close to the soil, does not require support and is used in Languedoc, Cyprus, Croatia, Spain and the Southern Rhône valley where it protects against the Mistral (a strong, cold, north-westerly wind that blows through the Rhône valley to the Mediterranean). I have witnessed the strength of this wind in Gigondas, in the Rhône valley, on a beautiful summer's day when it forced us to retreat indoors. The Guyot method of vine training [10] (a permanent main trunk plus one or two spurs), which is widely used today, was developed over 150 years ago.

So, remember it's hard to have a new idea and advances in haematology or wine are usually the result of many people's observations accumulated over time.

\section{Compliance with ethical standards}

Conflict of interest The author declares no competing interests.

Publisher's note Springer Nature remains neutral with regard to jurisdictional claims in published maps and institutional affiliations.

\section{References}

1. McCann SR. Covid-19, HCT and wine. Bone Marrow Transpl. 2020. https://doi.org/10.1038/s41409-020-0932-3.

2. Hyson MJ. Leech therapy: a history. J Hist Dent. 2005;53:25-27.

3. Davis A, Appel T. Bloodletting instruments in the National Museum of History and Technology. Washington D.C.: Smithsonian Institution Press; 1979.

4. McCann SR. A history of haematology: from Herodotus to HIV. Oxford, UK: Oxford University Press; 2016. ISBN 978-0-19871760-7\#.

5. Kim KH, Oh KY. Clinical applications of therapeutic phlebotomy. J Blood Med. 2016;7:139-44.

6. McCann SR. Can guidelines inhibit innovation and critical thinking? Bone Marrow Transpl. 2020. https://doi.org/10.1038/ s41409-020-0825-5.

7. Johnson H. The story of wine. London, UK: Mitchell Beazley, an imprint of Octopus Publishing Group Ltd; 2004. ISBN 978-184000-972-1.

8. Teeter A. https://vinepair.com/wineblog/the-first-wine-label-wasinvented-in-egypt. 2016.

9. Nesto B, Di Savino F. Chianti Classico. Oakland, CA: University of California Press; 2016. ISBN 978-0-520-28442-5.

10. McCann SR. Preparation for transplanting humans and planting vines. Bone Marrow Transplant. 2020. https://doi.org/10.1038/ s41409/02001132-6. 